\title{
Growth and Instability of Oilseed Production in Odisha during Kharif Season: A Statistical Study
}

\author{
Abhiram Dash* and Reendi Hansdah \\ Odisha University of Agriculture and Technology, Odisha, India \\ *Corresponding author
}

\section{A B S T R A C T}

\section{Keywords \\ compound growth rate, Coppock's instability index, production, significant}

\section{Article Info}

Accepted: 05 April 2020 Available Online: 10 May 2020
Oilseeds constitute a very important group of commercial crops in India and also in Odisha. Due to the economical values of these crops, these are considered as the most important crops all over the country as well as for the state of odisha. The present study aims at analyzing the district level growth and instability of oilseeds during kharif season in the state of Odisha from 1993-94 to 2016-17. The compound growth rate and Coppock's instability index are used as a measure of growth and instability of area, yield and production of kharif oilseeds. Also the districts of Odisha are ranked on basis of compound growth rate and Coppock's instability index of area, yield and production of kharif oilseeds. The compound growth rate of yield of kharif oilseeds in Odisha is positive and significant. But the significantly negative compound growth rate of area under kharif oilseeds is responsible for the significantly negative compound growth rate of production of kharif oilseeds.

\section{Introduction}

Odisha Agriculture is the major contributor to the state's economy. Agriculture is the chief occupation in Odisha. About $76 \%$ of the total working population is engaged with agriculture and agriculture related industries. Favorable climate and presence of rich soils accounts for the flourishing agriculture of Odisha. Oilseeds constitute a very important group of commercial crops in India and also in Odisha. The oil extracted from oilseeds form an important item of our diet and are used as raw materials for manufacturing large number of items like paints, varnishes, hydrogenated oil, soaps, perfumery, lubricants, etc.

The most commonly grown oilseeds in Odisha are groundnut, mustard, sesame, sunflower etc. Due to the economical values of these crops, these are considered as the most important crops all over the country as well as for the state of odisha. 
Primarily the oilseeds are grown for edible oil. Odisha has the total oilseed yield rate of $928 \mathrm{~kg} / \mathrm{ha}$ (Odisha Agricultural Statistics, Govt. of Odisha, 2015-16) which is less than the total oilseed yield of India i.e. $1153 \mathrm{~kg} / \mathrm{ha}$ according to the records of 2015-16. The study of growth and variability in area, yield and production of oilseeds is very important for effective planning and strategy formulation. The present study aims at analyzing the district level growth and instability of oilseeds during kharif season in the state of Odisha from 1993-94 to 2016-17. Keeping in view the above perspectives the study has been made regarding area, yield and production of oilseeds in all the 30 districts of Odisha for kharif seasons for the period 199394 to 2016-17. Dash, et al., (2017) studied the growth rate and instability of area, yield and production of food grain in Odisha using the best fit model and the model selected on the basis of scatter plot of the data.

\section{Materials and Methods}

The study is based on secondary source of data on area, yield and production of oilseed crops for kharif season in the districts of Odisha from the period 1993-94 to 2016-17. The data are obtained from various volumes of Odisha Agriculture Statistic published by Directorate of Agriculture and Food Production, Government of Odisha.

\section{Compound growth rate (CGR)}

The data on area, production and yield of oilseed crops for kharif season in Odisha were worked out for entire period of analysis by fitting to exponential functions as follows.

$Y_{t}=a b^{t}$

Where, $\mathrm{Y}_{\mathrm{t}}=$ Area / Production / Yield of kharif oilseeds in years. $\mathrm{t}=$ time element which takes the value $1,2,3, \ldots . ., \mathrm{n}$

$\mathrm{a}=$ intercept $; \mathrm{b}=$ regression coefficient

The compound growth model is established in the following manner,

$\ln \mathrm{Y}_{\mathrm{t}}=\ln \mathrm{a}+\mathrm{t} \ln \mathrm{b}$

$\mathrm{Y}_{\mathrm{t}}^{\prime}=\mathrm{A}^{\prime}+\mathrm{B}^{\prime} \mathrm{t}$

Let $\ln \mathrm{Y}_{\mathrm{t}}=\mathrm{Y}_{\mathrm{t}}{ }^{\prime}$

$\ln \mathrm{a}=\mathrm{A}^{\prime}$

$\ln \mathrm{b}=\mathrm{B}^{\prime}$

The two generalised equations are

$$
\begin{aligned}
& \sum_{t=1}^{n} Y_{t} t=\sum_{t=1}^{n}\left(A^{l}+B^{l} t\right) \\
& \sum_{\mathrm{t}=1}^{\mathrm{n}} \mathrm{Y}_{\mathrm{t}}^{\mathrm{l}}=\mathrm{nA}^{\mathrm{l}}+\mathrm{B}^{\mathrm{i}} \sum_{\mathrm{t}=1}^{\mathrm{n}} \mathrm{t} \\
& \sum_{\mathrm{t}=1}^{\mathrm{n}} \mathrm{tY}_{\mathrm{t}}^{\mathrm{l}}=\mathrm{A}^{\mathrm{i}} \sum_{\mathrm{t}=1}^{\mathrm{n}} \mathrm{t}+\mathrm{B}^{\mathrm{i}} \sum_{\mathrm{t}=1}^{\mathrm{n}} \mathrm{t}^{2}
\end{aligned}
$$
...equation 1 ... equation 2

Solving the two equations and multiplying equation 1 by $\sum_{\mathrm{t}=1}^{\mathrm{n}} \mathrm{t}$ on both sides we get

$$
\sum_{\mathrm{t}=1}^{\mathrm{n}} \mathrm{Y}_{\mathrm{t}}^{\mathrm{t}} \cdot \sum_{\mathrm{t}=1}^{\mathrm{n}} \mathrm{t}=\mathrm{nA} \mathrm{A}^{\mathrm{i}} \sum_{\mathrm{t}=1}^{\mathrm{n}} \mathrm{t}+\mathrm{B}^{\mathrm{i}}\left(\sum_{\mathrm{t}=}^{\mathrm{n}} \mathrm{t}\right)^{2} \quad \ldots \text { equation } 3
$$

Multiplying equation 2 by $\mathrm{n}$ on both sides we get

$$
\mathrm{n} \sum_{\mathrm{t}=1}^{\mathrm{n}} \mathrm{t} \mathrm{Y}_{\mathrm{t}}^{\mathrm{i}}=\mathrm{n} \mathrm{A}^{\mathrm{i}} \sum_{\mathrm{t}=1}^{\mathrm{n}} \mathrm{t}+\mathrm{nB}^{\mathrm{i}} \sum_{\mathrm{t}=1}^{\mathrm{n}} \mathrm{t}^{2}
$$
...equation 4

By Equation 3 - Equation 4 we get

$$
\mathrm{n} \sum_{\mathrm{t}=1}^{\mathrm{n}} \mathrm{t} \mathrm{Y}_{\mathrm{t}}^{\mathrm{l}}-\sum_{\mathrm{t}=1}^{\mathrm{n}} \mathrm{Y}_{\mathrm{t}}^{\mathrm{i}} \cdot \sum_{\mathrm{t}=1}^{\mathrm{n}} \mathrm{t}=\mathrm{nB}^{1} \sum_{\mathrm{t}=1}^{\mathrm{n}} \mathrm{t}^{2}-\mathrm{B}^{\mathrm{l}}\left(\sum_{\mathrm{t}=1}^{\mathrm{n}} \mathrm{t}\right)^{2}
$$




$$
\Rightarrow \quad B^{\prime}=\frac{n \sum_{t=1}^{n} t Y_{t}^{l}-\sum_{t=1}^{n} t \cdot \sum_{t=1}^{n} Y_{t}^{l}}{n \sum_{t=1}^{n} t^{2}-\left(\sum_{t=1}^{n} t\right)^{2}}
$$

Putting the value of $\mathrm{B}^{\prime}$ in equation 1 we get

$$
A=\left(\sum_{t=}^{n} Y_{t}^{1}-B \sum_{t=1}^{n} t\right) / n
$$

Given,

$\ln \mathrm{a}=\mathrm{A}^{\prime} ; \mathrm{a}=\mathrm{e}^{\mathrm{A}^{\prime}} ; \ln \mathrm{b}=\mathrm{B}^{\prime} ; \mathrm{b}=\mathrm{e}^{\mathrm{B}^{\prime}}$

Compound growth rate $($ C.G.R. $)=(b-1) X$ 100

$\mathrm{SE}(\mathrm{CGR})=\ln (\mathrm{b}) \quad \mathrm{x} \quad \mathrm{SE}(\ln \quad \mathrm{b}) / \ln 10$ (Dhakre and Sharma, 2010)

Coppocks instability index is a close approximation of the average year to year percentage variation adjusted for trend and the advantage is that it measures the instability in relation to the trend in prices. A higher numerical value for the index represents greater instability. It is represented by the following formula,

Coppock's instability index = Antilog $(\sqrt{\log V}-1) \times 100$

$$
\Rightarrow \log \mathrm{V}=\left(\sum_{t=1}^{n} \log \frac{X_{t+1}}{X_{t}}-m\right)^{2}
$$

Where $\log \mathrm{V}$ is the $\log$ variance;

$$
\mathrm{m}=\sum_{t=1}^{n} \log \frac{X_{t+1}}{X_{t}} \quad \text { (Anjum and Madhulika, }
$$$$
\text { 2018) }
$$

Here X represents production / area / yield $\mathrm{m}=$ mean value of successive differences of $\log$ values

\section{Spearman's rank correlation coefficient}

Spearman's rank correlation coefficient denoted by $\rho$ is a non-parametric measure of rank correlation. It assesses how well the relationship between two variables can be described using monotonic function.

The Spearman's correlation between two variables is equal to the Karl Pearson's correlation coefficient between rank values of those two variables and Pearson's correlation assesses linear relationships.

Spearman's formula for rank correlation coefficient,

$$
\rho=\frac{1-6 \sum_{i=1}^{n} d_{i}^{2}}{n\left(n^{2}-1\right)}
$$

Where,

$d_{i}=$ difference between two ranks of each observations

$\mathrm{n}=$ number of observations

\section{Test of significance of correlation coefficient}

The significance of the correlation is tested using t- test.

Let us assume the population correlation coefficient between Area \& Production and Yield \& Production be zero. So,

$\mathrm{H}_{0}: \rho=0$

$\mathrm{H}_{1}: \rho \neq 0$

Level of significance $(\alpha)=0.05(5 \%)$ or $0.01(1 \%)$

Test statistic is given by

$$
t_{\text {Cal }}=\frac{r}{S E(r)}
$$


$\mathrm{SE}(r)=\frac{1-\mathrm{r}^{2}}{\mathrm{n}-2}$

Tabulated $\mathrm{t}$ values are obtained from t-table. Tab t values are found for 0.05 and 0.01 level of significance at (n-2) d.f as the case may be. Let the Tabulated $t$ value for 0.05 and 0.01 level of significance be represented by $t_{1}$ and $\mathrm{t}_{2}$ respectively.

If $\left|t_{\mathrm{cal}}\right|>\mathrm{t}_{2}$ then we reject the null hypothesis at $1 \%$ level of significance. Here $t$ is considered to be highly significant and correlation between Area- Production and Yield -Production of two periods differ significantly at $1 \%$ level of significance.

If $\left|t_{\text {cal }}\right|<\mathrm{t}_{1}$ we accept null hypothesis. Here $\mathrm{t}$ is considered to be insignificant and we conclude that correlation don't differ significantly.

If $\mathrm{t}_{1}<\left|t_{\text {cal }}\right|<\mathrm{t}_{2}$, then we reject null hypothesis only at $5 \%$ level of significance. Here $t$ is considered to be significant and we conclude that correlation differs significantly at 5\% level of significance.

\section{Results and Discussion}

Table 1 show that though the compound growth rate of yield of kharif oilseeds in Odisha is positive and significant, the significantly negative compound growth rate of area under kharif oilseeds is responsible for the significantly negative compound growth rate of production of oilseeds.

Among the districts almost all districts also show negative compound growth rate of area under kharif oilseeds which is also significant in most cases. Most of the districts show positive compound growth rate in yield which is also significant.
Only a few districts like Dhenkanal, Nayagarh and Kendrapada show negative and significant compound growth rate in yield of kharif food grains. The compound growth rate of production is also negative and significant in many districts except a few like Angul, Malkangiri and Nuapada.

Table 2 shows that the in Odisha Instability is highest in case of production of kharif oilseeds than that in area and yield. Thus the high instability in production is due to interaction effect of area and yield. The districts like Nayagarh, Deogarh, Malkangiri and Sambalpur have very high rate of instability in production of kharif oilseeds which goes above $50 \%$. The instability in area and yield of kharif oilseeds is below $50 \%$ for all districts of Odisha though some districts have quite high rate (above 40\%) of instability.

Table 3 shows that Malkangiri district secured the first rank with respect to compound growth rate of area under kharif oilseeds followed by Sundergarh. Balasore districts has the last rank among the districts of Odisha on compound growth rate of area under kharif oilseeds. In case of instability of area under kharif oilseeds, Bargarh occupied the first position followed by Kendrapada and the last position is occupied by Nayagarh.

In case of compound growth rate of production of kharif oilseeds as evident from table 4, Malkangiri also secured first position followed by Boudh and last rank is occupied by Bhadrak. Kandhamal secured first position followed by Gajapati district and last rank is occupied by Khurdha with respect to $\mathrm{I}=$ instability in production of kharif oilseeds.

Table 5 shows that in case of compound growth rate of yield of kharif oilseeds, Bolangir district occupied the first position followed by Kalahandi and Jajpur districts 
and the last position is occupied by Nayagarh district. Jajpur secured first position followed by Bhadrak district and last rank is occupied by Deogarh with respect to instability in yield of kharif oilseeds. Table 6 which show the rank correlation coefficient between the compound growth rate and instability of area, yield and production of kharif oilseeds in Odisha, reveals that the rank correltion is significantly negative in case of area, whereas, in case of yield and production of kharif oilseeds it is positive but nonsignificant.

Table.1 Compound growth rate ( in \%) of kharif oilseeds of different districts of Odisha

\begin{tabular}{|c|c|c|c|c|c|c|c|c|c|}
\hline $\begin{array}{l}\text { Sl. } \\
\text { No. }\end{array}$ & Districts & Area & Yield & Production & $\begin{array}{l}\text { Sl. } \\
\text { No }\end{array}$ & Districts & Area & Yield & Production \\
\hline 1 & Angul & $-0.27 * *$ & $1.85^{* *}$ & $1.58 * *$ & 16 & Kandhamal & $-2.58 * *$ & -0.01 & $-2.60 * *$ \\
\hline 2 & Balasore & $-16.67 * *$ & $2.72 * *$ & $-14.40 * *$ & 17 & Kendrapada & $-8.47 * *$ & $-0.13^{* *}$ & $-8.59 * *$ \\
\hline 3 & Bargarh & -2.7 & $0.49 * *$ & $-2.22 * *$ & 18 & Keonjhar & $-2.64 * *$ & -1.51 & $-4.11 * *$ \\
\hline 4 & Bhadrak & -15.87 & 0.65 & -15.32 & 19 & Khurda & $-8.09 * *$ & $1.96^{* *}$ & $-6.28 * *$ \\
\hline 5 & Bolangir & $-7.73 * *$ & $5.16 * *$ & $-2.96^{* *}$ & 20 & Koraput & $-1.94 * *$ & 0.75 & $-1.21 * *$ \\
\hline 6 & Boudh & -0.04 & $2.53 * *$ & 2.48 & 21 & Malkangiri & $5.01 * *$ & $1.33 * *$ & $6.41 * *$ \\
\hline 7 & Cuttack & $-3.66^{* *}$ & $2.66 * *$ & -1.13 & 22 & Mayurbhanj & $-2.59 * *$ & 0.39 & $-2.21 * *$ \\
\hline 8 & Deogarh & -0.18 & 0.35 & 0.16 & 23 & Nabarangpur & $\begin{array}{l}- \\
13.07 *\end{array}$ & $3.14 * *$ & $-10.36^{* *}$ \\
\hline 9 & Dhenkanal & $-2.43^{* *}$ & $-0.95 * *$ & $-3.35^{* *}$ & 24 & Nayagarh & $-1.61 * *$ & $-3.07 * *$ & $-3.61 * *$ \\
\hline 10 & Gajapati & $-3.63 * *$ & -0.05 & $-3.68^{* *}$ & 25 & Nuapada & 0.01 & $1.70^{* *}$ & $1.72 * *$ \\
\hline 11 & Ganjam & $-1.24 * *$ & 0.39 & -0.84 & 26 & Puri & $-6.85^{* *}$ & -1.93 & $-8.42 * *$ \\
\hline 12 & Jagatsinghpur & -8.15 & $0.69 * *$ & -7.79 & 27 & Rayagada & $-2.04 * *$ & -0.92 & $-2.93 * *$ \\
\hline 13 & Jajpur & $-4.26^{* *}$ & $3.25^{* *}$ & $-1.14^{* *}$ & 28 & Sambalpur & $-6.14 * *$ & $1.30^{* *}$ & -4.92 \\
\hline 14 & Jharsuguda & 1.29 & $-0.04 * *$ & 1.23 & 29 & Subarnapur & -0.10 & $0.73^{* *}$ & 0.62 \\
\hline \multirow[t]{2}{*}{15} & Kalahandi & $-3.06 * *$ & $3.29 * *$ & 0.13 & 30 & Sundargarh & $1.52 * *$ & -0.29 & 1.21 \\
\hline & Odisha & $-2.11 * *$ & $1.36 * *$ & $-0.77^{* *}$ & & & & & \\
\hline
\end{tabular}

\footnotetext{
*signifies significant at 5\% and $* *$ signifies significant at $1 \%$
} 
Table.2 Coppock's Instability Index ( in \%) of kharif oilseeds of different districts of Odisha

\begin{tabular}{|l|l|l|l|l|l|l|l|l|l|}
\hline $\begin{array}{l}\text { SI } \\
\text { No. }\end{array}$ & Districts & Area & Yield & Production & $\begin{array}{l}\text { SI } \\
\text { No. }\end{array}$ & Districts & Area & Yield & Production \\
\hline $\mathbf{1}$ & Angul & 19.54 & 28.30 & 38.66 & 16 & Kandhamal & 21.54 & 12.33 & 30.73 \\
\hline $\mathbf{2}$ & Balasore & 10.42 & 18.47 & 25.22 & 17 & Kendrapada & 8.94 & 27.39 & 27.39 \\
\hline $\mathbf{3}$ & Bargarh & 8.46 & 17.49 & 21.80 & 18 & Keonjhar & 18.67 & 39.66 & 42.35 \\
\hline $\mathbf{4}$ & Bhadrak & 10.53 & 21.05 & 21.05 & 19 & Khurda & 46.80 & 52.74 & 59.24 \\
\hline $\mathbf{5}$ & Bolangir & 16.58 & 23.16 & 22.40 & 20 & Koraput & 10.68 & 26.91 & 33.55 \\
\hline $\mathbf{6}$ & Boudh & 20.72 & 34.99 & 52.17 & 21 & Malkangiri & 51.97 & 44.51 & 62.83 \\
\hline $\mathbf{7}$ & Cuttack & 41.66 & 26.39 & 40.52 & 22 & Mayurbhanj & 25.98 & 25.17 & 39.50 \\
\hline $\mathbf{8}$ & Deogarh & 66.24 & 32.35 & 72.39 & 23 & Nabarangpur & 31.40 & 44.45 & 60.99 \\
\hline $\mathbf{9}$ & Dhenkanal & 39.47 & 46.99 & 58.15 & 24 & Nayagarh & 86.74 & 34.46 & 60.62 \\
\hline $\mathbf{1 0}$ & Gajapati & 39.26 & 12.34 & 38.29 & 25 & Nuapada & 45.85 & 34.24 & 56.80 \\
\hline $\mathbf{1 1}$ & Ganjam & 18.92 & 23.41 & 40.79 & 26 & Puri & 9.27 & 14.87 & 14.87 \\
\hline $\mathbf{1 2}$ & Jagatsinghpur & 11.63 & 35.93 & 35.93 & 27 & Rayagada & 19.33 & 53.60 & 68.96 \\
\hline $\mathbf{1 3}$ & Jajpur & 19.49 & 43.83 & 44.06 & 28 & Sambalpur & 51.30 & 41.18 & 52.27 \\
\hline $\mathbf{1 4}$ & Jharsuguda & 44.93 & 32.98 & 61.84 & 29 & Subarnapur & 44.98 & 22.86 & 39.92 \\
\hline $\mathbf{1 5}$ & Kalahandi & 26.68 & 33.28 & 39.42 & 30 & Sundargarh & 44.36 & 45.32 & 31.39 \\
\hline & Odisha & $\mathbf{1 3 . 9 7}$ & $\mathbf{1 5 . 0 1}$ & $\mathbf{2 4 . 6 9}$ & & & & & \\
\hline
\end{tabular}

Table.3 Rank of the districts on basis of Compound growth rate( C.G.R) and Coppock's Instability Index(CII) of area under oilseeds for kharif season

\begin{tabular}{|c|l|c|c|c|l|c|c|}
\hline SI & & \multicolumn{2}{|c|}{ Kharif } & SI No. & Districts & \multicolumn{2}{|c|}{ Kharif } \\
\cline { 7 - 8 } No. & Districts & CGR & CII & & & CGR & CII \\
\hline $\mathbf{1}$ & Angul & 8 & 12 & 16 & Kandhamal & 14 & 13 \\
\hline $\mathbf{2}$ & Balasore & 30 & 4 & 17 & Kendrapada & 27 & 2 \\
\hline $\mathbf{3}$ & Bargarh & 17 & 1 & 18 & Keonjhar & 16 & 9 \\
\hline $\mathbf{4}$ & Bhadrak & 29 & 5 & 19 & Khurda & 25 & 26 \\
\hline $\mathbf{5}$ & Bolangir & 24 & 18 & 20 & Koraput & 11 & 6 \\
\hline $\mathbf{6}$ & Boudh & 5 & 14 & 21 & Malkangiri & 1 & 28 \\
\hline $\mathbf{7}$ & Cuttack & 20 & 21 & 22 & Mayurbhanj & 15 & 15 \\
\hline $\mathbf{8}$ & Deogarh & 7 & 29 & 23 & Nabarangpur & 28 & 17 \\
\hline $\mathbf{9}$ & Dhenkanal & 13 & 20 & 24 & Nayagarh & 10 & 30 \\
\hline $\mathbf{1 0}$ & Gajapati & 19 & 19 & 25 & Nuapada & 4 & 25 \\
\hline $\mathbf{1 1}$ & Ganjam & 9 & 10 & 26 & Puri & 23 & 3 \\
\hline $\mathbf{1 2}$ & Jagatsinghpur & 26 & 7 & 27 & Rayagada & 12 & 8 \\
\hline $\mathbf{1 3}$ & Jajpur & 21 & 11 & 28 & Sambalpur & 22 & 27 \\
\hline $\mathbf{1 4}$ & Jharsuguda & 3 & 23 & 29 & Subarnapur & 6 & 24 \\
\hline $\mathbf{1 5}$ & Kalahandi & 18 & 16 & 30 & Sundargarh & 2 & 22 \\
\hline
\end{tabular}


Table.4 Rank of the districts on basis of Compound growth rate( C.G.R) and Coppock's Instability Index(CII) of production under oilseeds for kharif seasons

\begin{tabular}{|c|l|c|c|c|l|c|c|}
\hline \multirow{2}{*}{ SI No. } & \multirow{2}{*}{ Districts } & \multicolumn{2}{|c|}{ Kharif } & \multicolumn{2}{c|}{ Sl } & Districts & \multicolumn{2}{c|}{ Kharif } \\
\cline { 3 - 7 } \cline { 6 - 8 } & CGR & CII & No. & & CGR & CII \\
\hline $\mathbf{1}$ & Angul & 4 & 14 & 16 & Kandhamal & 16 & 1 \\
\hline $\mathbf{2}$ & Balasore & 29 & 10 & 17 & Kendrapada & 27 & 13 \\
\hline $\mathbf{3}$ & Bargarh & 15 & 4 & 18 & Keonjhar & 22 & 22 \\
\hline $\mathbf{4}$ & Bhadrak & 30 & 5 & 19 & Khurda & 24 & 30 \\
\hline $\mathbf{5}$ & Bolangir & 18 & 8 & 20 & Koraput & 13 & 12 \\
\hline $\mathbf{6}$ & Boudh & 2 & 15 & 21 & Malkangiri & 1 & 28 \\
\hline $\mathbf{7}$ & Cuttack & 11 & 11 & 22 & Mayurbhanj & 14 & 9 \\
\hline $\mathbf{8}$ & Deogarh & 8 & 16 & 23 & Nabarangpur & 28 & 27 \\
\hline $\mathbf{9}$ & Dhenkanal & 19 & 29 & 24 & Nayagarh & 20 & 20 \\
\hline $\mathbf{1 0}$ & Gajapati & 21 & 2 & 25 & Nuapada & 3 & 19 \\
\hline $\mathbf{1 1}$ & Ganjam & 10 & 7 & 26 & Puri & 26 & 3 \\
\hline $\mathbf{1 2}$ & Jagatsinghpur & 25 & 21 & 27 & Rayagada & 17 & 24 \\
\hline $\mathbf{1 3}$ & Jajpur & 12 & 26 & 28 & Sambalpur & 23 & 25 \\
\hline $\mathbf{1 4}$ & Jharsuguda & 5 & 17 & 29 & Subarnapur & 7 & 23 \\
\hline $\mathbf{1 5}$ & Kalahandi & 9 & 18 & 30 & Sundargarh & 6 & 6 \\
\hline
\end{tabular}

Table.5 Rank of the districts on basis of Compound growth rate( C.G.R) and Coppock's Instability Index(CII) of yield under oilseeds for kharif season

\begin{tabular}{|l|l|l|l|l|l|l|l|}
\hline $\begin{array}{l}\text { SI } \\
\text { No. }\end{array}$ & Districts & Kharif & SI No. & Districts & \multicolumn{2}{l|}{ Kharif } \\
\hline $\mathbf{1}$ & CGR & CII & & & CGR & CII \\
\hline $\mathbf{2}$ & Balasore & 9 & 6 & 16 & Kandhamal & 21 & 19 \\
\hline $\mathbf{3}$ & Bargarh & 17 & 5 & 17 & Kendrapada & 24 & 8 \\
\hline $\mathbf{4}$ & Bhadrak & 16 & 2 & 19 & Khurda & 8 & 24 \\
\hline $\mathbf{5}$ & Bolangir & 1 & 11 & 20 & Koraput & 13 & 21 \\
\hline $\mathbf{6}$ & Boudh & 7 & 20 & 21 & Malkangiri & 11 & 29 \\
\hline $\mathbf{7}$ & Cuttack & 6 & 4 & 22 & Mayurbhanj & 19 & 17 \\
\hline $\mathbf{8}$ & Deogarh & 20 & 30 & 23 & Nabarangpur & 4 & 9 \\
\hline $\mathbf{9}$ & Dhenkanal & 27 & 12 & 24 & Nayagarh & 30 & 22 \\
\hline $\mathbf{1 0}$ & Gajapati & 23 & 13 & 25 & Nuapada & 10 & 27 \\
\hline $\mathbf{1 1}$ & Ganjam & 18 & 25 & 26 & Puri & 29 & 7 \\
\hline $\mathbf{1 2}$ & Jagatsinghpur & 15 & 18 & 27 & Rayagada & 26 & 26 \\
\hline $\mathbf{1 3}$ & Jajpur & 3 & 1 & 28 & Sambalpur & 12 & 28 \\
\hline $\mathbf{1 4}$ & Jharsuguda & 22 & 23 & 29 & Subarnapur & 14 & 10 \\
\hline $\mathbf{1 5}$ & Kalahandi & 2 & 16 & 30 & Sundargarh & 25 & 14 \\
\hline
\end{tabular}


Table.6 Rank correlation coefficient (RCC) between compound growth rate(CGR) and Coppock's Instability Index(CII) for area, yield and production of kharif oilseeds of Odisha

\begin{tabular}{|c|l|l|l|}
\hline & Area & Yield & Production \\
\hline RCC & -0.468 & 0.227 & 0.12 \\
\hline SE(standard erreor) & 0.167 & 0.184 & 0.188 \\
\hline \multicolumn{1}{c}{$\begin{array}{c}\text { Highly significant/Significant/Non } \\
\text { significant }\end{array}$} & $\begin{array}{l}\text { Highly } \\
\text { significant }\end{array}$ & $\begin{array}{l}\text { Non- } \\
\text { significant }\end{array}$ & Non-significant \\
\hline
\end{tabular}

The performance of kharif oilseeds as revealed from the analytical study is found to be poor with respect to area of kharif oilseeds. Though the yield performance is better than that of area, the performance should be enhanced to get a good increment in growth rate of yield of kharif oilseeds alongwith low degree of instability.

This could probably be achieved by putting some more area under oilseeds during kharif season if possible without sacrificing the more necessary food grains and by adopting improved cultivation practices for increasing the growth rate of yield. These steps are necessary for increasing growth rate of kharif oilseed production with decreased instability.

\section{References}

Anjum, S. and Madhulika (2018). Growth and Instability in Indian Agriculture, International Journal of Multidisciplinary Research and Development, 5(11):119-125

Dash, A. Dhakre, D.S and Bhattacharya, D. (2017). Study of Growth and Instability in Food Grain

Production of Odisha. A statistical approach, Environment and Ecology, 35(4):354-355.

Dhakre, D.S. and Sharma, A. (2010). Growth Analysis of Area, Production and Productivity of Maize in Nagaland, Agriculture Science Digest, 30(2):140144.

\section{How to cite this article:}

Abhiram Dash and Reendi Hansdah. 2020. Growth and Instability of Oilseed Production in Odisha during Kharif Season: A Statistical Study. Int.J.Curr.Microbiol.App.Sci. 9(05): 837844. doi: https://doi.org/10.20546/ijcmas.2020.905.093 